https://nv.nltu.edu.ua

https://doi.org/10.36930/40310408

$@$ Correspondence author

Article received 26.04.2021 p.

Article accepted 09.09.2021 p.

I. F. Shyshkanynets

schif@ukr.net

UDC $630 * 228.125$

І. Ф. Шишканинець, В. В. Лутак, В. С. Феннич

Національний природний парк "Зачарований край", с. Ільниия, Украйна

\title{
САНІТАРНИЙ СТАН ПОХІДНИХ ЯЛИНОВИХ НАСАДЖЕНЬ НАЦІОНАЛЬНОГО ПРИРОДНОГО ПАРКУ "ЗАЧАРОВАНИЙ КРАЙ"
}

Територія Національного природного парку "Зачарований край" розташована в центральній частині Вигорлат-Гутинської Вулканічної гряди (передгір'я Східних Карпат) і на 96,7 \% представлена лісовими землями. У породному складі явним домінантом є бук європейський (Fagus sylvatica L.) - 92 \%, на другому місці ялина європейська (Picea abies (L.) H. Karst.) $6,6 \%$, на решту порід припадає 1,4\% від площі вкритих лісовою рослинністю лісових ділянок. Регулярне вивчення стану насаджень на територіях природно-заповідного фонду - одне із завдань, покладених на науковий відділ Національного природного парку "Зачарований край". Оцінювання санітарного стану здійснювали переважно у літні місяці (липень-вересень) 2020 р. на дев'яти кругових постійних пробних площах, з використанням відповідних методик. Встановлено, що деревостани (зважаючи на санітарний стан ялини загалом) за індексом санітарного стану є дуже ослабленими - участь ялини у складі 3-4 одиниці, всихаючими - 7-8 одиниць, всохлими - 9-10 одиниць. За ступенем деградації фотосинтетичного апарату деревостани 3 участю ялини у складі 3-4 та 7 одиниць належать до класу "середньо ушкоджені", а деревостани 3 участю ялини у складі 8-10 одиниць - переважно до класу "дуже ушкоджені". Середня частка сухостійної деревини в загальному запасі збільшилася за 10-річний період від 2,9 до 37,8 \%. При цьому середня частка сухостійної деревини у змішаних деревостанах становить 21,8 \%, а у чистих та з переважанням участі ялини (8 і 9 одиниць) - 45,8 \%. Виявлено, що середня частка сухостійних дерев на пробних площах становить 63,5 \% - від кількості дерев ялини та 44,6 \% - від загальної кількості дерев. Середня частка сухостійних дерев у змішаних деревостанах становить 29,1\%, а у чистих та з участю ялини 9 і 8 одиниць $53,1 \%$. Масове всихання ялини призвело до переходу більшості деревостанів ялини, за елементом лісу, у всохлі насадження. Основними причинами деградації ялинових деревостанів $є$ осередки короїдів та абіотичні чинники (вітровали та буреломи), що призвели до механічних пошкоджень стовбурів.

Ключові слова: сухостійна деревина; індекс санітарного стану; дефоліація; пошкодження; клас Крафта.

\section{Вступ / Introduction}

Територія Національного природного парку (далі НПП) "Зачарований край" розташована у центральній частині Вигорлат-Гутинської Вулканічної гряди, передгір'я Східних Карпат, а саме - у межах хребта Великий Діл. Цей масив відділений від інших частин Вулканічної гряди долинами річок Латориця з північного заходу і Боржава з південного сходу. В адміністративному вимірі НПП розташований у межах Хустського району Закарпатської області. НПП "Зачарований край" створений на місці наявного впродовж 2002-2009 рр. регіонального ландшафтного парку "Зачарований край". До створення регіонального ландшафтного парку господарську діяльність здійснювали майже на $80 \%$ теперішньої площі парку, яка становила 6101 (з них 452 га земель без вилучення) га. Незважаючи на інтенсивну господарську діяльність в минулому, тільки 6,9 \% лісових земель за основним елементом лісу не відповідає займаним умовам місцезростання.

Територія парку на 96,7 \% зайнята лісовими землями. У породному складі явним домінантом є бук євро- пейський (Fagus sylvatica L.) - 92 \%, друге місце належить ялині європейській (Picea abies (L.) H. Karst.) $6,6 \%$, на решту порід припадає 1,4 \% від площі вкритих лісовою рослинністю лісових ділянок.

За даними проєкту організації території, iз 380,2 га похідних ялинових деревостанів на зону регульованої рекреації припадає 75,1 \%, господарську зону - 22,0 \%, заповідну зону $-2,9 \%$. За віком переважна більшість ялинових деревостанів належить до шостого (63,1 \%) та третього $(27,0 \%)$ класів віку (тривалість класу віку 10 років). За санітарним станом похідні ялинники панівного віку (50-70 років) здебільшого є сильно ослаблені (55,0 \%), здорових і ослаблених виявлено 36,0 \%, до категорії свіжий і старий сухостій віднесено 9,0\%. Частка похідних ялинників парку, які ростуть у вологій чистій бучині $\left(\mathrm{D}_{3}-Б к\right)$ та свіжій чистій бучині $\left(\mathrm{C}_{3}\right.$-Бк), становить 92,4 та 7,6 \% відповідно.

Об'єкт дослідження - похідні ялинові насадження Національного природного парку (НПП).

Предмет дослідження - санітарний стан та зміна лісівничо-таксаційних показників деревостанів.

Мета роботи - визначення санітарного стану та ди-

\section{Інформація про авторів:}

Шишканинець Іван Федорович, канд. с.-г. наук, заступник директора з наукової роботи. Email: schif@ukr.net

Лутак Василь Васильович, наук. співробітник. Email: locivinogr@gmail.com

Феннич Василь Степанович, т.в.о. директора. Email: zacharovanijkraj@ukr.net

Цитування за Дсту: Шишканинець І. Ф., Лутак В. В., Феннич В. С. Санітарний стан похідних ялинових насаджень Національного природного парку "Зачарований край". Науковий вісник НЛТУ України. 2021, т. 31, № 4. С. 54-58.

Citation APA: Shyshkanynets, I. F., Lutak, V. V., \& Fennich, V. S. (2021). Sanitary state of derivative spruce stands in Zacharovanyi Krai National Natural Park. Scientific Bulletin of UNFU, 31(4), 54-58. https://doi.org/10.36930/40310408 
наміки лісівничо-таксаційних показників насаджень за останне десятиріччя.

Для досягнення зазначеної мети визначено такі основні завдання дослідження: дослідити санітарний стан похідних ялинових насаджень та зміну основних таксаційних показників за останне десятиріччя.

Наукова новизна отриманих результатів дослідження - вперше на території НПП оцінено санітарний стан похідних ялинових насаджень.

Практична значущість результатів дослідження результати досліджень можуть бути використані під час розроблення нового (2021-2022 рр.) проєкту організації території НПП; наведено рекомендації для здійснення господарських заходів у похідних насадженнях НПП.

Аналіз останніх досліджень та публікацій. За останнє десятиліття стан деревостанів ялини європейської істотно погіршився в більшості типів лісу. Основними причинами швидкої масової деградації деревостанів Карпатського регіону є, безперечно, глобальні зміни клімату та масове вирощування ялини за межами іiі природного ареалу $[4,5,9]$. Варто зазначити, що процеси відмирання ялинових лісостанів є наслідком складної взаємодії комплексу причин. Визначальними чинниками, які призводять до загибелі лісостанів, є погодні умови посушливі періоди та падіння рівня грунтових вод [7].

Поширення всихання ялинових насаджень залежить від висотно-поясних, рельєфних і місцевих лісівничих умов регіону. Найбільш уразливими до всихання є насадження на висотах 400-900 м [11]. У віці 55-60 років більшість похідних ялинників досягає кількісної стиглості, яка відповідає середньому запасу 490-580 м³ га $^{-1}$ та інтенсивно пошкоджується кореневими гнилями [1]. Середні поточні збитки для Українських Карпат від всихання ялини сягають 12 тис. грн. га $^{-1}$ [15].

Унаслідок здійснення комплексних досліджень ялинових лісів Українських Карпат встановлено, що зі збільшенням віку похідних ялинників на схилах різних експозицій достовірно $\left(\mathrm{R}^{2}=0,98\right)$ зменшується площа насаджень, у яких всихання немає та істотно $\left(\mathrm{R}^{2}=0,96\right)$ збільшується площа насаджень сильного ступеня пошкодження [8]. Однак, щодо екологічних наслідків всихання ялинників Українських Карпат, то встановлено (у 91 \% випадків) як позитивні: динаміка фіторізноманіття спрямована на збільшення кількості видів рослин, так і негативні: погіршення їх киснепродукційних функцій [16].

Матеріали та методи дослідження. Оцінювання санітарного стану здійснювали переважно у літні місяці (липень-вересень) 2020 р. на дев'яти кругових пробних площах розміром 1000 м² (R-17,85 м). На пробній площі пронумеровували всі дерева діаметром 6 см і більше.

Обліки дерев виконували за 2-сантиметровими ступенями товщини, на висоті грудей (1,3 м), за породами. Висоту дерев вимірювали висотоміром Vertex у 9-ти дерев: середнього, верхнього та нижнього ступенів. При цьому здійснювали оцінювання дерев за категоріями технічної придатності [6], санітарним станом [14], видом пошкодження [10] та втратами асиміляційного апарату [3]. Для оцінки дефоліації використано атлас втрат асиміляційного апарату лісових дерев [2]. За дефоліацією дерев визначали середню величину ознаки для деревної породи та деревостану, і відносили деревостан за ушкодженням до одного з чотирьох ступенів: без ушкоджень (0) - дефоліація $\leq 10 \%$; слабо ушкоджені (1) 11-25 \%; середньо ушкоджені (2) - 26-60 \%; дуже ушкоджені (3) - 61-90\%; загиблі (4) - 91-100 \% [3].

Індекс стану деревостанів розраховували як середньозважений показник за такою формулою:

$$
I_{c}=\frac{1}{N} \sum_{j=1}^{N} K_{j} \cdot n_{j},
$$

де: $I_{c}-$ індекс стану деревостану; $K_{l} \ldots K_{N}-$ категорії стану дерев; $n_{1} \ldots n_{N}-$ кількість дерев кожної категорії стану; $N$ - загальна кількість врахованих дерев.

Якщо величина індексу стану не перевищує 1,5 , насадження вважають здоровим, 2,5 - ослабленим, 3,5 сильно ослабленим, 4,5 - всихаючим, 5,5 - всохлим [13].

\section{Результати дослідження та їх обговорення / Research results and their discussion}

Перед закладанням пробних площ проаналізовано матеріали лісовпорядкування, ліміти на використання природних ресурсів у межах територій та об'єктів загальнодержавного значення НПП "Зачарований край" від рубок формування і оздоровлення лісів (проєкти лімітів), щоб унеможливити вплив рубок за період 20112020 рр. на стан похідних ялинових насаджень НПП.

Пробні площі закладено у насадженнях панівної вікової категорії (50-70 років), які ростуть у вологій чистій бучині (пробні площі (далі ПП) 1Я, 2Я, 3Я, 5Я, 7Я, 8Я, 9Я) та свіжій чистій бучині (ПП 4Я, 6Я) і розміщені у межах 830-850 м н.р.м., окрім однієї: ПП 5Я - на висоті 664 м н.р.м. Щоб отримати основні дані для аналізу лісопатологічної ситуації та санітарного стану деревостанів, ми здійснили порівняльний аналіз зміни основних лісівничо-таксаційних показників насаджень за 10річний період (табл. 1).

Табл. 1. Лісівничо-таксаційна характеристика насаджень (чисельник - за матеріалами лісовпорядкування (2011 р.), знаменник - за матеріалами пробних площ) / Forest taxation characteristics of spruce plantations (nominator is based on forest taxation materials (2011), denominator is based on the materials from the sample areas)

\begin{tabular}{|c|c|c|c|c|c|c|c|c|c|c|c|}
\hline \multirow{2}{*}{$\begin{array}{l}\text { № } \\
\text { ПП }\end{array}$} & \multirow[b]{2}{*}{ Склад насадження } & \multirow{2}{*}{$\begin{array}{l}\text { Вік, } \\
\text { роки }\end{array}$} & \multicolumn{2}{|c|}{$D_{\text {cep, },}, \mathrm{cm}$} & \multicolumn{2}{|c|}{$H_{\text {cep. }}, \mathrm{M}$} & \multirow{2}{*}{$\begin{array}{c}\text { Повно- } \\
\text { та }\end{array}$} & \multirow{2}{*}{$\begin{array}{l}\text { Боні- } \\
\text { тет }\end{array}$} & \multicolumn{3}{|c|}{ Запас деревини, ${ }^{3 \circ} \cdot \mathrm{ra}^{-1}$} \\
\hline & & & Бкл & Ял & Бкл & Ял & & & $\begin{array}{c}\text { сиророс- } \\
\text { тучої }\end{array}$ & $\begin{array}{l}\text { сухос- } \\
\text { тійної }\end{array}$ & разом \\
\hline 19 & 10Яле/9Яле1Бкл & $58 / 68$ & $-/ 15$ & $26 / 33$ & $-/ 15$ & $24 / 24$ & $0,7 / 0,5$ & $\mathrm{I}^{\mathrm{a} / \mathrm{I}}$ & $440 / 278$ & $30 / 27$ & $470 / 305$ \\
\hline $2 Я$ & 10Яле+Бкл/10Яле+Бкл & $55 / 65$ & $-/ 14$ & $24 / 39$ & $-/ 14$ & $24 / 28$ & $0,8 / 0,3$ & $\mathrm{I}^{\mathrm{a} / \mathrm{I}^{\mathrm{a}}}$ & $500 / 245$ & $20 / 324$ & $520 / 569$ \\
\hline 39 & 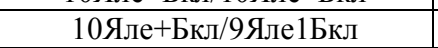 & $55 / 65$ & $-/ 12$ & $24 / 35$ & $-/ 12$ & $24 / 25$ & $0,8 / 0,2$ & $\mathrm{I}^{\mathrm{a} / \mathrm{I}^{\mathrm{a}}}$ & $500 / 140$ & $20 / 380$ & $520 / 520$ \\
\hline $4 Я$ & 8 Ял & $52 / 62$ & $24 / 20$ & $28 / 36$ & $24 / 24$ & $25 / 29$ & $0,8 / 0,75$ & $\mathrm{I}^{\mathrm{b} / \mathrm{I}^{\mathrm{b}}}$ & $480 / 374$ & 136 & $500 / 510$ \\
\hline $5 Я$ & $\begin{array}{c}\text { 6Яле1Яв2Бп1Бкл+Ос/4Яле5Бп } \\
\text { 1Бкл+Яв }\end{array}$ & $26 / 36$ & $12 / 12$ & $12 / 18$ & $12 / 14$ & $12 / 19$ & $0,7 / 0,8$ & $\mathrm{I}^{\mathrm{a}} / \mathrm{I}^{\mathrm{b}}$ & $150 / 289$ & $0 / 48$ & $150 / 337$ \\
\hline $6 Я$ & 8Яле2Бкл+Яв/6Бкл4Яле & $52 / 62$ & $24 / 22$ & $28 / 38$ & $24 / 26$ & $25 / 28$ & $0,7 / 0,7$ & $\mathrm{I}^{\mathrm{b} / \mathrm{I}^{\mathrm{b}}}$ & $430 / 411$ & $20 / 134$ & $450 / 545$ \\
\hline $7 Я$ & 8Яле2Бкл+Яв/7Яле3Бкл & $57 / 67$ & $18 / 16$ & $26 / 34$ & $18 / 21$ & $24 / 26$ & $0,8 / 0,6$ & $\mathrm{I}^{\mathrm{a} / \mathrm{I}^{\mathrm{a}}}$ & $410 / 329$ & $15 / 161$ & $425 / 490$ \\
\hline $8 Я$ & 8Бкл2Яле+Яв/8Яле2Бкл & $40 / 50$ & $18 / 18$ & $22 / 35$ & $17 / 22$ & $19 / 25$ & & $\mathrm{I} / \mathrm{I}^{\mathrm{a}}$ & $250 / 250$ & $0 / 213$ & $250 / 463$ \\
\hline 9 9Я & 10Яле/10Яле & $58 / 68$ & $-/-$ & $26 / 37$ & $-/-$ & $23 / 28$ & $0,6 / 0,3$ & $\mathrm{I}^{\mathrm{a} / \mathrm{I}^{\mathrm{a}}}$ & $360 / 212$ & $10 / 281$ & $370 / 493$ \\
\hline
\end{tabular}


Табл. 2. Показники стану похідних ялинових деревостанів (насаджень) НПП "Зачарований край" / The indices of sanitary conditions of the spruce stands (plantations) in Zacharovany Kraj National Nature Park

\begin{tabular}{|c|c|c|c|c|c|c|c|c|c|c|c|c|}
\hline \multirow{3}{*}{$\begin{array}{l}\text { № } \\
\text { ПП }\end{array}$} & \multicolumn{3}{|c|}{$\mathrm{N}$, шт. га $^{-1}$} & \multicolumn{2}{|c|}{ Клас Крафта } & \multicolumn{2}{|c|}{$\begin{array}{c}\text { Індекс санітарного } \\
\text { стану }\end{array}$} & \multicolumn{2}{|c|}{ Дефоліація } & \multicolumn{3}{|c|}{$\begin{array}{c}\text { Переважаючі пошкодження } \\
\text { ялини, шт. }\end{array}$} \\
\hline & \multirow[b]{2}{*}{ загальна } & \multicolumn{2}{|c|}{ Ял } & \multirow{2}{*}{$\begin{array}{c}\text { загаль- } \\
\text { ний }\end{array}$} & \multirow[b]{2}{*}{ Ял } & \multirow[b]{2}{*}{$\begin{array}{l}\text { загаль- } \\
\text { ний }\end{array}$} & \multirow[b]{2}{*}{ Ял } & \multirow[b]{2}{*}{ загальна } & \multirow[b]{2}{*}{ Ял } & \multirow[b]{2}{*}{ короїд } & \multirow{2}{*}{$\begin{array}{l}\text { витік } \\
\text { живиці }\end{array}$} & \multirow{2}{*}{$\begin{array}{c}\text { механічні } \\
\text { пошкоджен- } \\
\text { ня }\end{array}$} \\
\hline & & $\begin{array}{c}\text { сироросту- } \\
\text { ча } \\
\end{array}$ & $\begin{array}{l}\text { сухос- } \\
\text { тійна }\end{array}$ & & & & & & & & & \\
\hline 19 & 47 & 33 & 8 & 3,6 & 3,3 & 3,7 & 4,2 & 58,1 & 72,9 & 8 & 10 & 8 \\
\hline $2 Я$ & 65 & 15 & 47 & 4,4 & 4,4 & 5,2 & 5,4 & 88,8 & 92,1 & 47 & 4 & 2 \\
\hline $3 Я$ & 83 & 11 & 62 & 4,7 & 4,7 & 5,2 & 5,6 & 86,1 & 94,7 & 62 & 0 & 5 \\
\hline $4 Я$ & 92 & 9 & 21 & 3,7 & 4,1 & 3,4 & 5,3 & 46,5 & 91,3 & 21 & 3 & 0 \\
\hline $5 Я$ & 143 & 44 & 54 & 3,5 & 4,4 & 3,7 & 4,6 & 59,4 & 78,5 & 54 & 1 & 10 \\
\hline 69 & 78 & 10 & 16 & 3,7 & 4,0 & 3,1 & 5,0 & 43,8 & 85,4 & 16 & 1 & 2 \\
\hline $7 Я$ & 111 & 19 & 38 & 3,8 & 4,0 & 3,8 & 5,1 & 55,9 & 87,7 & 31 & 3 & 4 \\
\hline 89 & 72 & 17 & 39 & 4,2 & 4,3 & 4,4 & 5,1 & 71,9 & 86,7 & 39 & 0 & 12 \\
\hline $9 Я$ & 44 & 14 & 30 & 4,0 & 4,0 & 4,9 & 4,9 & 85,0 & 85,0 & 30 & 1 & 4 \\
\hline
\end{tabular}

За матеріалами шести пробних площ (ПП 1Я, 2Я, 3Я, 5Я 7Я, 9Я) склад насаджень не має істотної різниці 3 матеріалами лісовпорядкування, а за матеріалами трьох пробних площ (ПП 4Я, 6Я, 8Я) - інший: відбулася зміна головної породи (див. табл. 1). Істотне розходження за складом на трьох пробних площах можна пояснити переважно куртинним зростанням ялини у насадженні, де і були закладені пробні площі та, очевидно, всиханням ялини. Збільшення частки бука за матеріалами пробних площ у складі насаджень, особливо в ялиново-букових деревостанах, пояснюють значним погіршенням санітарного стану ялини та іiі всиханням (сухостійні дерева ялини під час визначення складу деревостану до уваги не брали).

Середній діаметр ялини збільшився у середньому на 40,0 \%, а бука - зменшився на 8,0 \% (до переліку взято дерева діаметром від 6 см). Також відзначено відповідні зміни середніх висот, однак на бонітет це не вплинуло.

Повнота у чистих ялинових деревостанах та у деревостанах 3 домішкою бука (1-2 одиниці) знизилася майже у два рази, а у змішаних деревостанах (ПП 4Я, 5Я, 6Я, 7Я) майже не змінилася.

Щодо загального запасу деревини, то за матеріалами восьми пробних площ він збільшився у середньому на 23,0 \% порівняно 3 матеріалами лісовпорядкування, а на першій пробній площі - зменшився. Зниження запасу на ній можна пояснити зниженням бонітету (велика кількість дерев, внаслідок вітролому, із механічно пошкодженими верхівками). Запаси сухостійної деревини збільшилися у середньому майже у 13 разів, а сироростучої - дещо зменшилися на всіх пробних площа, окрім п'ятої, на якій збільшення участі берези у складі насадження стало причиною зростання запасу.

Середня частка сухостійної деревини в загальному запасі за матеріалами лісовпорядкування є значно меншою і становить 2,9 \%, а за матеріалами пробних площ - 37,8 \%. При цьому середня частка сухостійної деревини у змішаних деревостанах (ПП 4Я, 5Я, 6Я) становить $21,8 \%$, а у чистих та 3 переважанням участі ялини (8 i 9 одиниць) $-45,8 \%$.

Зважаючи на значне збільшення частки сухостійної деревини у загальному запасі та враховуючи динаміку всихання, похідні ялинові насадження парку можуть не досягнути віку технічної стиглості, який настає у 7180 років [1]. Якщо брати до уваги кількість дерев, то середня частка сухостійних дерев на пробних площах становить: 63,5 \% - від кількості дерев ялини та 44,6 \% від загальної кількості дерев (табл. 2). Середня частка сухостійних дерев у змішаних деревостанах становить
$29,1 \%$, а у чистих та 3 участю ялини 9 і 8 одиниць $53,1 \%$.

Аналізуючи отримані дані щодо індексу санітарного стану ялинників, визначено, що насадження (зважаючи на санітарний стан ялини загалом) НПП "Зачарований край" поділяють на сильно ослаблені (участь ялини у складі 3-4 одиниці), всихаючі (участь ялини 7-8 одиниць), всохлі (участь ялини 9-10 одиниць). Отже, масове погіршення стану ялини та її всихання призводить до переходу більшості деревостанів ялини, за елементом лісу, у всохлі насадження.

Варто зазначити, що подібна ситуація із погіршенням санітарного стану триває і в Українських Карпатах загалом: особливо інтенсивне погіршення санітарного стану відбувається в насадженнях складу 9-10 одиниць ялини та в низькоповнотних деревостанах [8].

За ступенем деградації фотосинтетичного апарату деревостани з участю ялини у складі 3-4 та 7 одиниць належать до класу "середньо ушкоджені", а деревостани 3 участю ялини у складі 8-10 одиниць - переважно до класу "дуже ушкоджені".

Причинами погіршення санітарного стану є механічні пошкодження внаслідок вітровалів і буреломів та осередки масового розмноження короїдів (переважно Ips typographus L., короїд-типограф). На окремих деревах виявлено трутовик облямований (Fomitopsis pinicola Swartz ex Fr.), який спричиняє буру деструктивну гниль стовбурів ослаблених дерев. Плодових тіл кореневої губки (Heterobasidion annosum s.1.) не виявлено під час обстеження.

Велика частка сухостійних дерев ялини відобразилася і на значеннях середнього класу Крафта: клас Крафта ялини відповідає загальному класу Крафта, незважаючи на те, що живі дерева ялини за висотою є значно вищі за бука. Варто зазначити, що для моніторингу санітарного стану похідних ялинових деревостанів деякі пробні площі було закладено 2017 р. У 2020 р. на них (ПП 1Я, 5Я) здійснено повторне оцінювання санітарного стану. Встановлено, що індекс санітарного стану значно погіршився: на ПП 1Я - від 3,6 до 4,2, а на ПП 5Я від 2,5 до 3,8 одиниць. При цьому на першій пробній площі зроблено аналіз за 33 деревами, що становить 80,0 \% від загальної кількості дерев ялини, а на п'ятій за 46 деревами, що становить 47,0 \% відповідно. Тому індекс санітарного стану деревостанів упродовж трьох років погіршився: 3 ослаблених - у сильно ослаблені.

Щодо господарської діяльності, то рубки головного користування на ревізійний період 2014-2023 pp. не проєктували, а експлуатаційний фонд ялини похідної 
призначено у санітарну рубку суцільну. При цьому, зважаючи на щорічний обсяг здійснення заходів 3 поліпшення санітарного стану лісів (санітарних рубок) на доступних для їх проведення ділянках зони регульованої рекреації і господарської зони: санітарні рубки суцільні заплановано провести на площі 20 га, упродовж 5 років; санітарні рубки вибіркові - на площі 96,6 га, упродовж 7 років.

Упродовж 2011-2020 рр. у похідних ялинниках санітарні рубки суцільні проведено на площі 12,3 га, а вибіркові - на площі 26,0 га. Отже, план щодо санітарних рубок суцільних виконано на $61,5 \%$, а вибіркових - на $26,9 \%$. Варто зазначити, що невеликі обсяги здійснення санітарно-оздоровчих заходів $€$ наслідком непогодження проєктів лімітів (незважаючи на санітарний стан похідних ялинників) Мінприроди України у 2014-2016 pp. (у проєктах лімітів об'єми природоохоронних заходів перевищували обсяги, зазначені проєктом організації території).

Однак, чи достатньо щорічних обсягів санітарних заходів з транспортно-доступних ділянок (передбачених проєктом організації території), щоб запобігти масовому всиханню похідних ялинників парку? Очевидно, що ні: санітарно-оздоровчі заходи заплановано здійснити тільки на площі 116,6 га. При цьому проєктом організації території установи не передбачено динаміки всихання.

Обговорення результатів дослідження. Результати досліджень свідчать, що санітарний стан похідних ялинових деревостанів за 10-річний період значно погіршився. Та кількість санітарно-оздоровчих заходів (санітарних рубок), яку здійснено в НПП, виявилась недостатньою, щоб запобігти масовому всиханню ялинників. Основними причинами погіршення санітарного стану, як і для Карпатського регіону загалом $[4,5], \epsilon$, безперечно, глобальні зміни клімату та масове вирощування ялини за межами її природного ареалу.

Якщо за дослідженнями, здійсненими в Українських Карпатах у 80-х роках ХX ст. [1], більшість похідних ялинників досягають кількісної стиглості у 55-60 років, яка відповідає середньому запасу 490-580 $\mathrm{m}^{3} \cdot \mathrm{ra}^{-1}$, то за нашими даними: у віці 55 років (ПП 1Я, 2Я, 3Я, 4Я, 6Я, 7Я, 9Я), за матеріали лісовпорядкування середній запас (сироростучої деревини) становить $446 \mathrm{~m}^{3} \cdot \mathrm{ra}^{-1}$, а у віці 65 років, за матеріалами пробних площ $-284 \mathrm{~m}^{3} \cdot \mathrm{ra}^{-1}$ (див. табл. 1). При цьому запас у середньому зменшився на $162 \mathrm{~m}^{3} \cdot \mathrm{ra}^{-1}$, а участь ялини у складі - від 9 до 7 одиниць. 3 огляду на наведене вище, вік кількісної стиглості у похідних ялинових насадженнях дещо змістився і настає у 50-55 років.

Вчасне виконання санітарних рубок могло б принести в бюджет парку значні кошти. При цьому на площах, зайнятих похідними ялинниками, пріоритетним завданням має бути відтворення і формування корінних мішаних деревостанів, у складі яких, відповідно до типу лісу, повинні панувати бук, ялиця та їх супутники [12]. Ялина у складі корінних деревостанів букових типів лісу є доцільною тільки у вигляді домішки до $30 \%$.

\section{Висновки / Conclusions}

Похідні ялинові деревостани (зважаючи на санітарний стан ялини загалом) за індексом санітарного стану $\epsilon$ : дуже ослабленими - участь ялини у складі 3-4 одиниці, всихаючими - 7-8 одиниць, всохлими - 9-10 оди- ниць. При цьому насадження ялини за елементом лісу всохле. За ступенем деградації фотосинтетичного апарату деревостани з участю ялини у складі 3-4 та 7 одиниць належать до класу "середньо ушкоджені", а деревостани з участю ялини у складі 8-10 одиниць - переважно до класу "дуже ушкоджені". Середня частка сухостійної деревини в загальному запасі збільшилася за 10-річний період від 2,9 (матеріали лісовпорядкування) до 37,8 \% (матеріали пробних площ). При цьому середня частка сухостійних дерев на пробних площах становить: $63,5 \%$ - від кількості дерев ялини та 44,6 \% - від загальної кількості дерев.

Основними причинами деградації ялинових деревостанів $є$ осередки короїдів та абіотичні чинники (вітровали та буреломи), що призвели до механічних пошкоджень стовбурів.

Рекомендації. Невідкладних санітарно-оздоровчих заходів потребують похідні ялинові деревостани, а саме: санітарних рубок суцільних - деревостани з участю ялини у складі 10 одиниць, санітарних рубок вибіркових - деревостани з участю ялини до 6 одиниць. У деревостанах $з$ участю ялини 7-9 одиниць доцільніше виконувати рубки переформування. Відповідні рекомендації наведено, виходячи з постанови КМУ за № 124 від 9 грудня 2020 р., складу деревостанів та їх санітарного стану.

Під час розроблення нового проєкту організації території потрібно переглянути функціональне зонування території: вилучити похідні ялинові насадження зі заповідної зони парку.

\section{References}

1. Bigun, N. Y. (1990). Elniki bukovoj zony Karpat. Spruce forests of the beech zone of the Carpathians. Uzhgorod, Karpaty, $125 \mathrm{p}$. [In Russian].

2. Borecki, T., \& Keczynski, A. (1992). Atlas of the loss of the assimilation apparatus in forest trees. Warszawa, Agencia Reklamowa "ATUT", 49 p. [In Poland).

3. Buksha, I. F., \& Banik, M. V. (2001). Methodical recommendations on forest monitoring of Ukraine of the I level. Kharkiv: UkrNDILHA, 33 p (In Ukrainian].

4. Debrynyuk, Y. M. (2011). Dying of spruce forests: causes and consequences. Scientific ulletin of UNFU, 21(16), 32-38. [In Ukrainian].

5. Holubets, M. A. (2016). Bases to restorefunctional essenceof the Carpathian forests. Lviv, Manuskript, 144 p. [In Ukrainian].

6. Hrom, M. M. (2007). Forest assessment. Lviv, RVV NLTU Ukrainy, 416 p. [In Ukrainian].

7. Kramarets, V. O., \& Matsiakh, I. P. (2017). Forest declines: causes, consequences, possible ways of counteraction. Scientific Principles of Biodiversity Conservation, 8(15), 45-62. [In Ukrainian].

8. Kramarets, V. O. (2021). Spruce forest stands of the Ukrainian Carpathians: current conditions and increase of biotic stability. Extended abstract of Doctor dissertation. Lviv, 48 p. [In Ukrainian].

9. Kramarets, V. O., \& Krynytskyy, H. T. (2009). Assessment and possible threats to the survival of the spruce forests of the Carpathians in connection with climate change. Scientific Bulletin of UNFU, 19(15), 38-50. [In Ukrainian].

10. Mozolevskaya, E. G., Kataev, O. A., \& Sokolova, E. S. (1984). Methods of forest pathological examination of foci of stem pests and forest diseases. M. Lesn. rrom-st, 152 p. [In Russian].

11. Oliinyk, V. S., \& Zeinalian, A. M. (2020). Altitude features of spruce decline on the north-eastern megaslope of Ukrainian Carpathians. Foresty and Forest Melioration, 136, 19-24. https://doi.org/10.33220/1026-3365.136.2020.19

12. Parpan, V. I., Shparyk, Yu. S., Slobodyan, P. Ya., Parpan, T. V., et al. (2014). Forest management peculiarities in secondary Nor- 
way spruce (Picea abies (L) H. Karst.) stands of the Ukrainian Carpathians. Proceedings of the Forestry Academy of Sciences of Ukraine, 12, 20-29. [In Ukrainian].

13. Pasternak, P. S., et al. (1987). Recommendations for increasing the resistance of greenery to man-made air pollution by emissions of ammonia, sulfur dioxide, nitrogen oxides in the forest and steppe zones of the Ukrainian SSR: Methodikal instructions. Kharkov: UkrNIILKhA, 16 p. [In Russian].

14. Sanitary Forests Regulations in Ukraine. (2016). Postanova Kabinetu Ministriv Ukrayiny vid 26 zhovtnya 2016, No 756. Retrieved from: https://zakon.rada.gov.ua/laws/show/1224-2020-D0BFText (last accessed date 09.12.2020)

15. Shparyk, Y. S. (2017). Economic results of spruce forests declinein the Ukrainian Carpathians. Proceedings of the Forestry Academy of Sciences of Ukraine, 15, 129-139. https://doi.org/10.15421/411717

16. Shparyk, Y. S. (2019). Ecological results of Norway spruce forests decline in main forest types of the Ukrainian Carpathians. Proceedings of the Forestry Academy of Sciences of Ukraine, 19, 145-153. https://doi.org/10.15421/411915

I. F. Shyshkanynets, V. V. Lutak, V. S. Fennich

Zacharovanyi Krai National Nature Park, Ilnytsia, Ukraine

\section{SANITARY STATE OF DERIVATIVE SPRUCE STANDS IN ZACHAROVANYI KRAI NATIONAL NATURAL PARK}

Zacharovany Kraj National Nature Park is located in the central part of the Vyhorlat-Hutyn Volcanic Ridge (the Eastern Carpathians foothills), and $96.7 \%$ of its area are represented by forested lands. The European beech (Fagus sylvatica L.) is a dominant tree species ( $92 \%$ ) followed by the European spruce (Picea abies (L.) H. Karst.) (6.6 \%), while other tree species comprise only $1.4 \%$ of the forest vegetation. The regular monitoring of green spaces at the Nature Reserve Fund areas is one of the tasks of Zacharovany Kraj National Nature Park research department. Sanitary conditions of the spruce stands (based on the sanitary condition of spruce in general) were assessed mainly during July-September 2020 at nine circular permanent test plots using the relevant methodology. The sanitary condition index of the spruce stands was defined as "very weakened", when spruce comprised 3-4 units, "drying" - 7-8 units, and "dead wood" - 9-10 units. Moreover, based on the degree of photosynthetic apparatus degradation the spruce stands were characterized as "moderately damaged" (if spruce comprised 3-4 and 7 units), and "extremely damaged" (8-10 units respectively). The average portion of dead wood in the total forest area increased from 2.9 to $37.8 \%$ over the last decade. Next, the average portion of dead wood in mixed stands is $21.8 \%$, and in pure stands and stands with spruce input at the level of 8 and 9 units is $45.8 \%$. It was revealed that the average portion of dead wood in the surveyed areas comprised $63.5 \%$ of the spruces number, and $44.6 \%$ of the total tree number. The average portion of dead wood in mixed stands was $29.1 \%$, while in pure stands and stands with spruce input at the level of 8 and 9 units it was $53.1 \%$. The massive drying of the spruce stands caused the transition of the spruce forests to the dried woods. The key reasons of the spruce stands degradation are the bark beetle abundancy and abiotic stress factors (e.g., windfalls and windbreaks) enhancing the mechanical damage of tree stems.

Keywords: dead wood; sanitary condition index; defoliation; damage; Krafts classification. 